\title{
Bioengineering cytotoxic $T$ cells to target opportunistic fungal infection
}

\author{
Pappanaicken Kumaresan ${ }^{1 *}$, Pallavi R Manuri ${ }^{1}$, Nathaniel Albert ${ }^{2}$, Brian Rabinovich ${ }^{1}$, Simon Olivares ${ }^{1}$, \\ Sourindra N Maiti ${ }^{1}$, Helen Huls ${ }^{1}$, Dean A Lee ${ }^{1}$, Dimitrios Kontoyiannis ${ }^{2}$, Laurence J Cooper ${ }^{1}$ \\ From Society for Immunotherapy of Cancer 28th Annual Meeting \\ National Harbor, MD, USA. 8-10 November 2013
}

Clinical-grade $\mathrm{T}$ cells are genetically modified ex vivo to express chimeric antigen receptors (CARs) to redirect their specificity to target tumor-associated antigens in vivo. We have developed gene therapy approach to render $\mathrm{T}$ cells specific for invasive fungal infections (IFI) due to Aspergillus. We adapted the pattern-recognition receptor Dectin-1 to activate $\mathrm{T}$ cells via chimeric $\mathrm{CD} 28$ and CD3-zeta (designated D-CAR) upon binding with carbohydrate cell wall in Aspergillus germlings. T cells genetically modified with Sleeping Beauty system to stably express D-CAR were selectively propagated on artificial antigen presenting cells using an approach that is approved by FDA to develop CAR $\mathrm{T}$ cells for clinical trials. The D-CAR+ T cells exhibited specificity for beta-1,3gucan and damaged and thus inhibited hyphal growth of Aspergillus. Treatment of D-CAR+ T cells with steroids did not compromise anti-fungal activity. Thus, we report a clinically-appealing strategy to transfer innate immunity for mycology to cytotoxic $\mathrm{T}$ cells.

\footnotetext{
Authors' details

'Department of Pediatrics, MDACC, Houston, TX, USA. '2Department of Infectious Disease, MDACC, Houston, TX, USA.
}

Published: 7 November 2013

doi:10.1186/2051-1426-1-S1-P4

Cite this article as: Kumaresan et al:: Bioengineering cytotoxic $\mathrm{T}$ cells to target opportunistic fungal infection. Journal for ImmunoTherapy of Cancer 2013 1(Suppl 1):P4.
${ }^{1}$ Department of Pediatrics, MDACC, Houston, TX, USA

Full list of author information is available at the end of the article
Submit your next manuscript to BioMed Central and take full advantage of:

- Convenient online submission

- Thorough peer review

- No space constraints or color figure charges

- Immediate publication on acceptance

- Inclusion in PubMed, CAS, Scopus and Google Scholar

- Research which is freely available for redistribution

Submit your manuscript at www.biomedcentral.com/submit
C Biomed Central
() Biomed Central

(c) 2013 Kumaresan et al; licensee BioMed Central Ltd. This is an Open Access article distributed under the terms of the Creative Commons Attribution License (http://creativecommons.org/licenses/by/2.0), which permits unrestricted use, distribution, and reproduction in any medium, provided the original work is properly cited. 